\title{
Case report: Herpes zoster in a healthy 5 month old infant
}

\section{Olgu sunumu: Sağlıklı 5 aylık bebekte herpes zoster}

\author{
*Göknur Özaydın Yavuz, İbrahim Halil Yavuz ${ }^{1}$, Hatice Uce Özkol ${ }^{1}$, Serap Güneş \\ Bilgili $^{1}$
}

${ }^{1}$ Department of Dermatology, Yüzüncü Y1l University School of Medicine, Van, Turkey.
Corresponding author: Dr. Göknur Özaydın Yavuz, Dermatoloji Anabilim Dalı, Yüzüncü Y11 Üniversitesi, TR 65080,
Van, Türkiye
E-mail: goknuroz1 @ gmail.com
Received/Accepted: March 09, 2015/September 10, 2015
Conflict of interest: There is not a conflict of interest.

\section{SUMMARY}

Varicella zoster virüs (VZV) is a common viral infectious agent that causes chickenpox in childhood. Herpes zoster (HZ) is a latent infection that is caused by VZV, which is localized in the cells of dorsal root ganglions. Although the disease is commonly seen among elderly people and immunosuppressive individuals, it is rarely observed in healthy children. In our case report we present a 5-months aged patient without any immunosuppressive disease or undergoing varicella disease who was diagnosed as Herpes Zoster.

Keywords: Herpes zoster, healthy children, infant

\section{ÖZET}

Varisella zoster virüsü (VZV) çocuklarda suçiçeğine sebep olan sık görülen bir viral infeksiyon ajanıdır. Herpes zoster (HZ), arka kök ganglion hücrelerine yerleşen VZV tarafından oluşturulan latent infeksiyondur. Hastalık, yaşlı ve immünsüppresif kişiler arasında sık görülmesine rağmen, sağlıklı çocuklarda nadiren gözlenir. Bu vakada 5 aylık, immunsupresif bir hastalığı olmayan ve daha önce suçiçeği geçirmediği bildirilen herpes zoster tanısı koyduğumuz bir hasta sunulmuştur.

Anahtar sözcủkler: Herpes zoster, sağlıkli çocuk, infant.

\section{INTRODUCTION}

Herpes zoster (HZ) is a disease which holds a single sensory nerve or its dermatome with the effect of latent varicella virus (VZV) settled into dorsal root ganglion, old age, immunosuppression and unknown various triggering factors. For $2 \%$ of the patients subjected to intrauterine $\mathrm{VZV}$, chickenpox is transmitted subclinically and they have a risk to develop $\mathrm{HZ}$ infection after birth ${ }^{1-2}$. Although it is a common disease in older ages, it is rare to be under 1 years old. In this paper, we present 5 month old baby with $\mathrm{HZ}$ as a case.

\section{CASE REPORT}

5 month old baby girl was taken to our clinic with the complaint of bulging full of water in the body. Her family said the baby was restless and had a mild fever for 3 days. Systemic examination of the baby was normal while plaques on which there were a large number of vesicles were present on the region starting from abdomen and extending to lumbar region and the region matching to thoracic 8-9 dermatomes, erythematous base, on dermatological examination (Figure 1, 2). Routine laboratory studies were normal.

Tzanck smears taken from patients were evaluated under the microscope and multinucleated giant cells were detected. As a result of physical examination and Tzanck smear, the patient was diagnosed with HZ. Treatment with systemic acyclovir syrup 
and topical fusidic acid cream was started. Lesions was markedly reduced after 5 days.

\section{DISCUSSION}

Varicella zoster virus is an enveloped and double-stranded DNA virus belonging human herpes virus family. After passing the primary varicella infection, virus remains latent through settling dorsal root ganglia of the sensory nerve. Herpes zoster disease occurs as a result of reactivation of virus due to various reasons ${ }^{3-4}$. Chickenpox is seen frequently in children of 5-9 years while $\mathrm{HZ}$ is usually seen in people over 50 years old. Incidence in children aged zero to 14 years is $0.45 / 1000$, while it is 4.2 $4.5 / 1000$ for over 75 years. The majority of cases having $\mathrm{HZ}$ in childhood is 5 years old and older ${ }^{5}$. Our case was 5 months old baby.

Typical involvement regions were reported as thoracic $(53 \%)$, cervical $(20 \%)$, ophthalmic $(15 \%)$ and lumbosacral $(11 \%)^{3}$ Thoracic dermatome involvement is present in our patient. Clinically, HZ begins as erythematous and painful, then vesicles occurs on. After 1 week, vesicles are scabbed and gets better with ulcerated areas. Similar clinical onset was present in our case. $\mathrm{HZ}$ cases were also reported after varisella vaccination ${ }^{6}$. If no history of varicella in children, intrauterine varicella infection should be considered in $\mathrm{HZ}$ babies. HZ is seen in the first 12 months (240 month range) on the babies exposed to intrauterine varisella. Congenital varicella syndrome may occur in the babies exposed to varisella before 20 weeks of pregnancy ${ }^{7}$ ${ }^{8}$. Our patient had no history of vaccination and the mother was thought to be infected during pregnancy because it was a nurse. However, there were no signs of congenital varicella syndrome in physical examination.

The diagnosis of $\mathrm{HZ}$ in babies is based on anamnesis, physical examination and laboratory investigations. The diagnosis was made physical examination and Tzanck test in our patient. Serological tests were not performed. The differential diagnosis of HZ should be done with herpes simplex infection, contact dermatitis, erythema multiforme, cellulitis and impetigo ${ }^{2-9}$. It was separated from other diseases with the presence of dermatomal involvement, lack of cantact anamnesis in our patient and Tzanck test.

In healthy children, HZ usually is recovered within 1-3 weeks without complication and antiviral treatment is not needed very much. Only supportive treatment can be given. However, antiviral treatment is recommended in association with cranial nerve involvement, pain in the acute phase, congenital or acquired immunodeficiency syndrome and atopic dermatitis ${ }^{1-9}$. Systemic acyclovir therapy was given since there was discomfort and early start in our patient. Although HZ seen in babies is selflimiting disease, you need to be careful since it can be seen in malignancy and immunosuppressive conditions ${ }^{2-9}$.

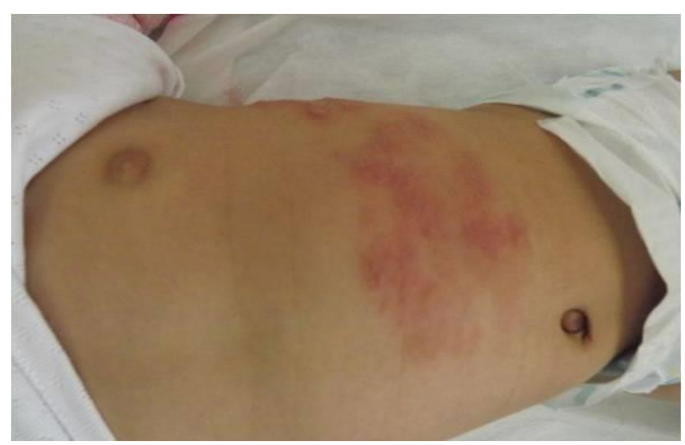

Figure 1: Generalized grouped vesicles on dermatomally located erythematous base in the abdomen of the case.

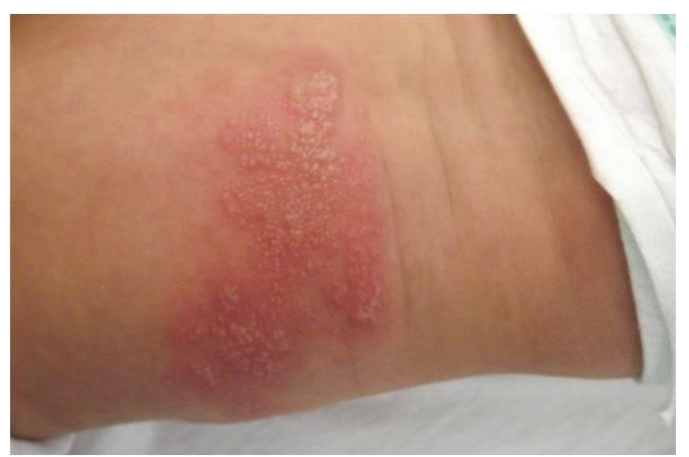

Figure 2: Appearance of lumbar region of the case.

\section{REFERENCES}

1. Özuğuz P, Kaçar SD, Polat S Karaca Ş, Kundak A. Çocukluk çağı zona zoster: 12 olgu sunumu. Abant Med J 2014; 3: 253-6.

2. Mondal A, Sinha N, Kumar P. Grouped vesicular lesions in an in- 
fant. Indian Pediatr 2013; 50:

1180.

3. Çicek D. İnfantil dönemde bir herpes zoster olgusu. Firat Tip Dergisi 2007; 12: 313-4.

4. Yaghoobi R, Feily A, Naderpazyar, Khazanee A, Rafiee S, Salehi SM. Infantile herpes zoster after intrauterine exposure to varicella infection. Acta Med Indones 2012; 44: 256-7.

5. Çölgeçen E, Küçük Ö, Balcı M.Çocukluk çağı herpes zoster infeksiyonun klinik özellikleri. Türkderm 2012; 46: 26-8.

6. Obieta MP, Jacinto SS. Herpes zoster after varicella vaccination in a healthy young child. Int J Dermatol 2008; 47: 640-1.

7. Pupco A, Bozzo P, Koren G. Herpes zoster during pregnancy. Can Fam Physician 2011; 57: 1133.

8. Deguchi E, Imafuku S, Nakayama J. A case of infantile herpes zoster in an infant born to a mother infected with varicella at 7 weeks of pregnancy. J Dermatol 2011; 38: 622-4.

9. Çıkım ÇA. Sağlıklı çocukta herpes zoster. Türkderm 2009; 43: 177-9. 